Arkiv. Tidskrift för sambällsanalys, $\mathrm{nr} 6$ (2016)

Festskriftsavdelning: Göran Therborn 75 år

\title{
Festskriftsavdelning: Göran Therborn 75 år (inledning)
}

\section{Sven Hort}

SAmmandrag: Samtidigt med detta nummer ger Arkiv förlag ut boken Class, Sex and Revolutions. Göran Therborn - A Critical Appraisal där ett tjugotal författare från fyra kontinenter behandlar centrala teman i den svenske världssociologens samhällsvetenskapliga produktion över mer än fem decennier. Den här "festskriftsavdelningen” är en svensk pendang till den boken. Den öppnar med Anita Göranssons och Karin Widerbergs kritiska diskussion av Therborns Between Sex and Power. Family in the World, 1900-200o (2004) som parallelt publiceras i Class, Sex and Revolutions. Därefter följer två artiklar av Mats Svegfors och Olle Svenning, två samhällsdebattörer från motsatta politiska läger vilka båda mötte Göran Therborn i Lund på 1960-talet och som följer hans tänkande och samhällsutvecklingen från det årtiondet, då "allting var i rörelse”, fram till i dag. Avdelningen avslutas med Gunnar Olofssons översikt över de böcker och småskrifter som gavs ut av tidskriften Zenit, som Therborn var med och "nygrundade" 1967, åren 1968-1982.

NYCKelord: Göran Therborn; Class, Sex and Revolutions; familjeinstitutionen; välfärdsstat; socialdemokrati; tidskriften Zenit.

PUBLICERINGSHISTORIK: Originalpublicering.

SVEN HORT är professor vid institutionen för samhällsstudier vid Linnéuniversitetet och professor emeritus vid Department of Social Welfare vid Seoul National University i Sydkorea.

E-POSTADRESS: sven.hort@lnu.se

FÖRSLAG PÅ KÄLLANGIVELSE:

Hort, Sven (20I6) Inledning till "Festskriftsavdelning: Göran Therborn 75 år", i Arkiv. Tidskrift för sambällsanalys, nr 6, s. 59-60.

DoI: http://dx.doi.org/I0.I3068/2000-6217.6.F

(C) Sven Hort/Arkiv förlag \& tidskrift 2016 (publicerad 7 oktober 20ı6)

Artikeln distribueras enligt en upphovsrättslicens från Creative Commons:

Erkännande-Ickekommersiell-IngaBearbetningar 3.0 Unported, som medger fri ickekommersiell användning och spridning i oförändrat skick så länge källan anges. 
Arkiv. Tidskrift för samhällsanalys är en sakkunniggranskad vetenskaplig tidskrift för samhällsvetenskap och historia. Samtliga artiklar publiceras fritt tillgängliga på:

www.tidskriftenarkiv.se

Beständig länk, DoI: http://dx.doi.org/IO.I3068/2000-62I7

Den här artikeln finns tillgänglig i följande format:

PDF \& HTML: via beständig länk, DOI: http://dx.doi.org/IO.I3068/2000-62I7.6.F EPUB: ingår i e-boksutgåva av numret, ISBN: 978 9I 79242794

TRYCK: ingår i bokutgåva av numret, ISBN: 978 9I 7924280 O

Grafisk utformning och sidnumrering är identisk i pdf och tryck.

Samtliga artiklar i nr 6 (20ı6) nås via beständig länk, DOI: http://dx.doi.org/I0.I3068/2000-6217.6

Arkiv. Tidskrift för sambällsanalys ISSN: 2000-62I7 (för elektronisk resurs)

ISSN: 2000-6225 (för tryckta nummer)

ges ut av

Stiftelsen Arkiv för främjande och spridning av samhällsvetenskaplig och historisk forskning

genom

Arkiv förlag \& tidskrift

Box 1559

SE-22I OI Lund

ВESÖK: L Gråbrödersg 3 c, ipg

TEL: 046-I3 3920

ARKIV FÖRLAG: arkiv@arkiv.nu·www.arkiv.nu

TIDSKRIFTEN ARKIV: red@tidskriftenarkiv.se · www.tidskriftenarkiv.se

ANSVARIg UTGIVARE \& CHEFREDAKTÖR: Sven Hort

ADMINistrativ RedAKTÖr: David Lindberg

ReDAKTörer: Paavo Bergman, Lisa Kings, Zhanna Kravchenko 


\section{FESTSKRIFTSAVDELNING}

\section{Göran Therborn 75 år}

Samtidigt med detta nummer ger Arkiv förlag ut boken Class, Sex and Revolutions. Göran Therborn - A Critical Appraisal där ett tjugotal författare från fyra kontinenter behandlar centrala teman i den svenske världssociologens samhällsvetenskapliga produktion över mer än fem decennier. Therborn har sedan länge passerat pensionsstrecket, ändå är han vid ingången till sitt "färde kvartal" mer aktiv än någonsin. Nästa år utkommer Cities of Power. The Urban, the National, the Popular, and the Global och han reser fortfarande från världsdel till världsdel och presenterar sina bidrag till analyser av den samtida riktningen i de mänskliga samhällenas - "moderniteternas" - förändringsprocesser. Hans arbetsspråk är numera genomgående engelska. Samtidigt går han emot den starka likriktning av samhällsvetenskaplig forskning som präglar dagens akademiska produktion i form av artiklar på standardiserad tidskriftsamerikanska, vanligtvis skrivna för de närmast sörjande. Förmodligen är ingen nu levande svensk samhällsvetare översatt till fler språk än Göran Therborn, från arabiska till japanska, kinesiska och koreanska. Och spanska förstås, han är läst och spridd i de många delar av världen där samhällsvetenskap fortfarande är en kontroversiell och omstridd praxis, inte minst i Latinamerika. Exakta uppgifter om spridningen av hans arbeten är svåra att få fram; inget svenskt bibliotek tycks ha någon samlad dokumentation av vad forskaren och hans många översättare åstadkommit genom åren, emellanåt långt från lycksalighetens egen halvö. 
Några artiklar av Göran Therborn har tidigare översatts och publicerats i denna tidskrift, senast texterna om det tjugoförsta århundradets klasser och massor i nr 3 (20I4). Therborn gjorde entré 1976 med en för tidskriften bearbetad version av ett kapitel ur sin monumentala doktorsavhandling Science, Class and Society: "Marx, Engels och den historiska materialismens uppkomst" (Arkiv för studier i arbetarrörelsens historia $\mathrm{nr}$ 9-IO). Sammanlagt har det i denna tidskrift blivit nio artiklar varav en samförfattad. Som student och ung aktivist var Göran Therborn en gång också mycket påtagligt närvarande i svensk samhällsdebatt, inte minst som huvudredaktör till 1966 års En ny vänster (på Rabén \& Sjögren) och som en av den en gång ungsyndikalistiska tidskriften Zenits nygrundare 1967. När Class, Sex and Revolutions koncipierades tillfrågades också några samhällsdebattörer från olika delar av den svenska offentligheten om bidrag till denna kompletterande svenska "festskriftsavdelning". Mats Svegfors och Olle Svenning, vilka båda mötte Göran Therborn i Lund på 1960-talet, knyter an till de ovan nämnda artiklarna i "nya" Arkiv (nr 3, 20I4) och berör på olika sätt den numera synnerligen historiska tid då "allting var i rörelse" - och rörelsens förlängningar både bakåt i tiden och in i nuet. En av alla dessa 6o-talsrörelser vilken då tog fart och som fortlever med stor kraft är den feministiska och från Class, Sex and Revolutions är Anita Göranssons och Karin Widerbergs kritiska diskussion av Therborns Between Sex and Power. Family in the World, I900-2000 (2004) hämtad. Artikeln är översatt av Sven-Erik Torhell, granskad och godkänd av författarna. Till denna avdelning har också fogats Gunnar Olofssons översikt över tidskriften Zenits bokutgivning åren 1968-1982. 

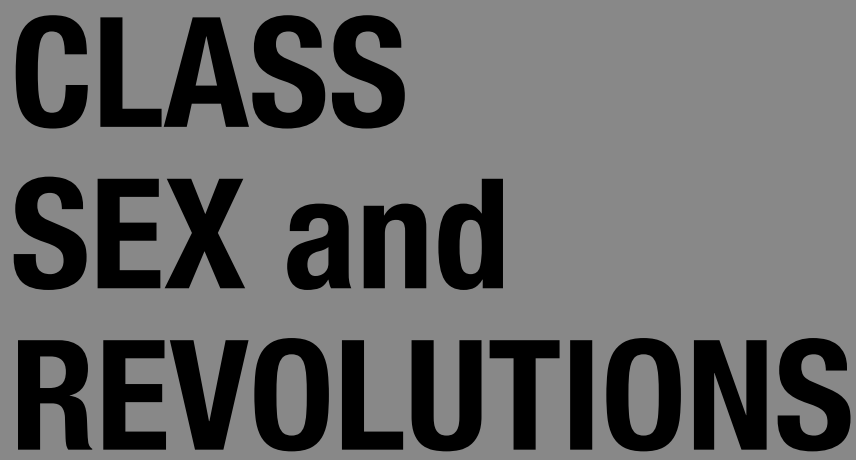

\section{Göran Therborn - a critical appraisal}

In between Science, Class and Society (1976) and The Killing Fields of Inequality (2013) Göran Therborn has consistently challenged received wisdom in politics and the social sciences. Today his work is spread across six continents, Latin America in particular, and has been translated into more than twenty languages.

This book is a critical appraisal of the themes Göran Therborn has pursued up till now, and is introduced by Robin Blackburn, for almost twenty years his editor at New Left Review. The book is edited by Gunnar Olofsson and Sven Hort.

Contributors include among others Perry Anderson, Chang Kyung-sup, Anita Göransson, Eric Hobsbawm, Habibul Haque Khondker, Åsa Cristina Laurell, Lena Lavinas, Bo Rothstein, Anders Stephanson, Immanuel Wallerstein, Karin Widerberg, Erik Olin Wright and Elisabeth Özdalga.

\section{ARKIV FÖRLAG, 436 pages}




\section{Böcker av Göran Therborn från Arkiv förlag}

Ojämlikhet dödar

2I2 sidor, Arkiv förlag 2016

Borgarklass och byråkrati i Sverige

Anteckningar om en solskenshistoria

I86 sidor, Arkiv förlag I989

Nationernas ofärd

Arbetslösheten i den internationella krisen

223 sidor, Arkiv förlag 1985

Maktens ideologi och ideologins makt

I34 sidor, Zenit 198I i distribution från Arkiv förlag

Kapitalism och rösträtt

Om den borgerliga demokratins uppkomst

67 sidor, Arkiv förlag I980

Vad gör den härskande klassen när den härskar?

Statsapparater och statsmakt under

feodalism, kapitalism och socialism

309 sidor, Zenit 1980 i distribution från Arkiv förlag

Frankfurtskolan

Till kritiken av den kritiska teorin

84 sidor, Arkiv förlag 1976

Klasser och ekonomiska system

328 sidor, Zenit 1971 i distribution från Arkiv förlag

"Böckerna går att beställa i bokhandeln och från www.arkiv.nu“ 